Results The guardians described that 13 of them were infected (11 women and two men). Among the total number of interviewees, only 7 individuals stated that the form of transmission would be through oral contact and/or sexual violence, and $47.14 \%$ of the total reported not knowing how the HSV is transmitted. Among the children, the guardians reported that 6 had at least one episode of infection.

Conclusion The research showed that, in general, there is a lack of knowledge about the herpes infection. It is also evident, that the lack of knowledge can contribute in to diagnosis delay, in the possibility of household's transmission and hindering the prevention of infectious complications.

\section{P3.06 INITIAL EVALUATION OF VIRAL LOAD IN PEOPLE LIVING WITH HIV IN CAMAÇARI, ONE OF THE FOUR MOST POPULATED CITY IN BAHIA, BRAZIL}

A Farias, P Farias, R Penna, A Borges. Reference Centre in HIV/STI, Camaçari, Brazil

\subsection{6/sextrans-2017-053264.243}

Introduction: There are many different ways to control HIV epidemic today, instead of condom. In fact, because HIV treatment has demonstrated the most substantial effect on HIV incidence, it will be impossible to end the epidemic without bringing treatment to all patients living with the virus. Then, this study tries to analyse how the patients are well controlled in their HIV viral load in Camaçari, one of the most comercial and populated city in the state of Bahia, a northeast area in Brazil.

Methods Between November 2015 and November 2016, it was collected some data from about 236 of all 492 patients who have been cared to HIV at the only Centre of treatment in Camaçari, a service that has been assisted by a multidisciplinary team like Infectious Diseases assistance, Gynaecologist, Psychologist, Pharmaceutical, Nutritionist and Social Service.

Results $80,5 \%(190)$ of 236 patients had viral load in the blood less than 1000 copies $/ \mathrm{ml}$. These, 46,84\%(89) were men, $53,16 \%(101)$ were women. The average age was 39 years old and medium age was 40 . From the patients who were under control, 73,16\%(139) were taking two nucleoside inhibitors plus one non nucleoside inhibitor and from all, 64,74\%(123) were using Tenofovir, Lamivudine and Efavirenz as a single dosage per day, as Brazilian guideline recommended. 19,5\% (46) had more than 1000 copies/ml. 58,7\%(27) were men and $41,3 \%(19)$ were women. The average age was 40 years old and medium age was 37. Patients who weren't under viral load control were divided in three different groups: genotype needed $(28,26 \%)$, problems with antirretroviral adherence $(34,78 \%)$ and necessities to start medication quickly (36,96\%). A multidisciplinary group was created to help patients in these conditions, especially for better adherence.

Conclusion It's really possible to get undetectable viral load in $90 \%$ from all patients by 2020 , maybe even more in certain circumstances, based on Brazilian public health care system and defining strategies to change detectable in suppressed viral load, like getting a multidisciplinary team with health care providers.
P3.07 SEXUAL PROFILE AND PSYCHOSOCIAL ASPECTS OF A GROUP OF HIV INFECTED WOMEN IN RIO DE JANEIRO

${ }^{1}$ AAS Helena, ${ }^{2}$ DC Ferreira, ${ }^{3}$ MRL Passos, ${ }^{4}$ AJ Giesteira*, ${ }^{5} \mathrm{HLB}$ Reis, ${ }^{6} \mathrm{~S}$ Muchele, ${ }^{6} \mathrm{R}$ Peres. ${ }^{1}$ Mestre em Materno Infantil - UFF, Brazil; ${ }^{2}$ Professor da UNESA e UVA, Brazil; ${ }^{3}$ Professor Titular e chefe do setor de DST - UFF, Brazil; ${ }^{4}$ Mestranda em Materno Infantil - UFF, Brazil; ${ }^{5}$ Doutoranda - UFES, Brazil; ${ }^{6}$ Farmacêutica - UNIIABEU, Brazil

\subsection{6/sextrans-2017-053264.244}

Introduction Women living with HIV have special features that arouse the interest of the scientific community, once they bring in themselves subjectivities that are beyond questions of clinical order. The objective of this study was to identify the patients' sexual and psychosocial profile of a public hospital in the state of Rio de Janeiro.

Methods A cross-sectional study and a semi structured interview with $70 \mathrm{HIV}$-infected women was carried out from April 2012 to March 2013. The patients were from an AIDS outpatient service of a hospital in Nova Iguaçu, in the State of Rio de Janeiro.

Results The average age of the participants was 34.9 years $(\mathrm{SD}= \pm 11.2)$. More than half of women 55 (78.6\%) acquired the infection through sexual intercourse. As for the marital status, 27 (38.6\%) were single and 29 (41.4\%) were married/ stable union. $68(97.2 \%)$ reported heterosexual orientation and $42(60 \%)$ reported having active sexual life. Half of these women had occupation/employment, and few had already left the job because of infection, they reported that companies they worked at had no knowledge about the disease. The most common reasons cited were prejudice and by considering a matter of personal agenda. As for the self-perception, 38 $(54.3 \%)$ of the evaluated women showed no satisfaction with their bodies, and 21 (30\%) experienced a possible reduction of libido after infection. The use of HAART occurred in 51 $(72.9 \%)$ patients, and even those classified as their biggest challenges in achieving treatment: adherence and access to the hospital, both with its implications.

Conclusion Our findings demonstrate the need to develop further health strategies in order to contribute to the comprehensive care that is being provided to these women, regarding their social reinsertion (occupation/employment), education, risk behaviour and preventive practices, serodiscordant relationships, disclosure, satisfaction with body and also the adherence to the proposed treatment.

\section{P3.08 STI PREVALENCE AND CORRELATES OF MORAL JUDGMENT AND BELIEF OF HIV TRANSMISSION THROUGH CASUAL CONTACT IN ADOLESCENTS ATTENDING PUBLIC HIGH SCHOOLS IN TWO DISTRICTS IN PANAMA}

${ }^{1} \mathrm{~A}$ Gabster, ${ }^{2} \mathrm{~GB}$ Arteaga, ${ }^{1} \mathrm{~A}$ Martinez, ${ }^{3} \mathrm{E}$ Mendoza, ${ }^{1} \mathrm{~J}$ Dyamond, ${ }^{1} \mathrm{O}$ Castillero, ${ }^{1} \mathrm{~J}$ Castillo, ${ }^{1} \mathrm{~A}$ López, ${ }^{1} \mathrm{~N}$ Mojica, ${ }^{1,2} \mathrm{JM}$ Pascale. 'Instituto Conmemorativo Gorgas de Estudios de la Salud, Panama, Panama; ${ }^{2}$ Facultad de Medicina, Universidad de Panamá, Panama, Panama; ${ }^{3}$ Facultad de Ciencias Naturales, Exactas y Tecnología, Universidad de Panamá, Panamá, Panamá

\subsection{6/sextrans-2017-053264.245}

Introduction Moral judgments (MJ) against people living with HIV (PLHIV), and belief of HIV transmission through casual contact (CC), lead in varying to degrees to social exclusion, discrimination, and violence. This study estimates the prevalence of HIV and other sexually transmitted infections (STI), 